DOI:10.17951/h.2021.55.3.23-36

\begin{tabular}{lcc}
\hline \multicolumn{1}{c}{ A N N A L E S } \\
UNIVERSITATIS MARIAE CURIE-SKŁODOWSKA \\
LUBLIN - POLONIA \\
VOL. LV, 3 & SECTIOH H \\
\hline
\end{tabular}

\author{
JAN BRAUN \\ jan.braun@poczta.umcs.lublin.pl \\ Maria Curie-Skłodowska University. Faculty of Economics \\ 5 Maria Curie-Skłodowska Sq., 20-031 Lublin, Poland \\ ORCID ID: https://orcid.org/0000-0002-5762-0046 \\ PATRYCJA MARZEC-BRAUN \\ patrycja.marzec@poczta.umcs.lublin.pl \\ Maria Curie-Skłodowska University. Faculty of Economics \\ 5 Maria Curie-Skłodowska Sq., 20-031 Lublin, Poland \\ ORCID ID: https://orcid.org/0000-0001-7593-6901
}

\title{
Participatory Budget as One of the Instruments of the Concept of Public Governance on the Example of the City of Lublin
}

Keywords: new public management; public governance; participatory budget

JEL: H72; M19; M48

How to quote this paper: Braun, J., \& Marzec-Braun, P. (2021). Participatory Budget as One of the Instruments of the Concept of Public Governance on the Example of the City of Lublin. Annales Universitatis Mariae Curie-Skłodowska, sectio H-Oeconomia, Vol. 55, No. 3.

\footnotetext{
Abstract

Theoretical background: Participatory budgeting enables the co-creation of local budgets through discussions between residents and local authorities. Thanks to this, it is possible to implement those investments that are important for the local community. By voting, the citizens may participate in the process of creating local development.

Purpose of the article: The purpose of the article is the diagnosis of the concept of public governance and tools used within the framework of co-management, with particular emphasis on the participatory budget on the example of the city of Lublin in 2015-2021.
} 
Research methods: The analysis covered existing data from budget resolutions of individual cities, reports from the Lublin Research Group and from Internet sources. The publication includes both quantitative and qualitative research.

Main findings: The participatory budget of Lublin is characterized by a relatively high share of funds allocated to the implementation of tasks in total budget expenditure compared to other provincial cities in Poland. For several years, there has also been a noticeable decline in the turnout of people voting for projects under the participatory budget. Thanks to a detailed analysis of the functioning of the participatory budget of the city of Lublin, compared to other provincial cities in Poland, there is a need to promote the idea of social participation more strongly.

\section{Introduction}

Currently, the solutions used by the public sector undoubtedly have a significant impact on the quality of the society life. Therefore, there is a need to constantly improve the quality of governance, which should serve a local community (Kargol-Wasiluk \& Wojewódko, 2016, p. 156). Undoubtedly, the participation of citizens in making decisions relating to the local community is part of the above-mentioned trend of thought. Active involvement of residents in the affairs of a given local government unit may contribute to an increase in the effectiveness of local government administration activities (Rybczyńska, 2002, pp. 113-114).

The aim of the publication is to diagnose the concept of public governance and tools used in public governance, with particular emphasis on the participatory budget on the example of the city of Lublin in 2015-2021. The authors focused on characterizing Lublin's participatory budget in terms of its application and popularity among the local community. Additionally, it was compared with the participatory budgets of other provincial cities. For this purpose, the existing data from the budget resolutions of individual cities, reports of the Lublin Research Group [Lubelska Grupa Badawcza] and Internet sources were subjected to critical analysis. The study includes both quantitative and qualitative research.

\section{The idea of public governance as an effect of the development of new public management}

The second half of the $20^{\text {th }}$ century was a time of huge changes in the economies of Western European countries, mainly related to the criticism of the applied model of state administration. The growing importance of the services market, and hence the increased competition between entities, translated into more sophisticated consumer preferences regarding the quality of service provision. As a result, expectations towards public administration changed significantly and took on a completely new approach on the part of citizens. The variety of mass media contributed to the growth of social awareness and influenced the involvement of the population in public affairs (Sempiak, 2017, p. 145). In order to eliminate numerous imperfections 
of the public sector, new public management (NPM) was initiated, which focused on tools and methods ensuring the achievement of appropriate economic efficiency and effectiveness in the undertaken activities, while focusing all opportunities on results (Stefańska, Bubel, \& Barcik, 2019, p. 138).

The reforms related to the new approach to managing public institutions were caused by the expansion of the public sector, the political and economic crisis, as well as the crisis of values in traditional public administration. Opportunities were sought for changes in the area of excessive employment, return to subsidiarity, but also focused on increasing modernity by introducing information technologies and establishing international cooperation (Jasińska, 2015, p. 71). Efforts were made to achieve socio-economic effects with low expenditure, based on improving the quality of services provided in public administration and limiting the bureaucratic model used so far (Myszak, 2012, p. 113).

A review of the literature on the subject shows the existence of many definitions of NPM. Nevertheless, the essence of NPM is to change the management orientation in public organizations, assuming the abandonment of the classic model in favor of initiating rules consisting in the analysis of results related to the expenses incurred, focusing on strategic orientation, as well as introducing an efficient market mechanism enabling providing public services at a high level (Zalewski, 2006, p. 74). Organizations using NPM strive to decentralize power, create flexible structures and methods of operation, while promoting ethical behavior and managerial professionalism based on knowledge and experience. They also focus on the concept of management by objectives, taking full responsibility for results and exercising control, while managing the staff perfectly through appropriate motivation. It is also extremely important to improve the competitiveness, which they achieve thanks to customer orientation, creating services in line with the demand and a high level of their provision (Sempiak, 2017, p. 139).

On the one hand, NPM has several significant advantages. Namely, it obliges to use market mechanisms and focuses on the use of modern management methods and tools. On the other hand, it is criticized because it is too market-oriented. It focuses on reducing costs and improving the efficiency of public organization, ignoring the issues related to the effectiveness of the organization in terms of meeting social needs (Szumowski, 2014, p. 93). Therefore, the idea of NPM was aimed at striving to improve the efficiency and rationality of actions in entities and public services (Rudolf, 2010, p. 75).

As a result of market needs and the growing wave of criticism, a new, broader approach has emerged on the basis of NPM - public governance (PG), taking into account the complexity of relations on the socio-political and economic level. PG relates to effective and efficient activities of public entities within the interaction with external entities, which is possible thanks to complex management, which includes connections between a large number of stakeholders (Szumowski, 2014, p. 94). This concept refers to a new management culture replacing hierarchical structures with 
networks of cooperation between private and public partners, as well as non-profit organizations, which can be seen mainly at the local level (Kotowska, 2015, p. 33). As a result, the goal of PG is to "(...) involve citizens, on the basis of partnership, in the governing process. The government as well as local institutions must take into account the aspirations and expectations of citizens" (Ziębicki, 2014, p. 147).

PG is a specific activity oriented towards networking, tendency to compromise, multi-level management, dialogue and participation, aimed at shared responsibility and democratization of the management system (Jessop, 2007). PG focuses on the internal organization of the public sector, its institutions, as well as relations with the external environment. However, the most important thing is to focus on citizens treated as co-decision makers and co-creators of the common good. It is also important that the existing relationships are based on trust and significant autonomy (Lenart, 2015, p. 311).

Therefore, PG creates a previously unknown framework for the development of democracy, treating civil society as a network of social organizations. According to the assumptions of PG, public tasks are entrusted to the sphere of entities consisting of the civil society. The cooperation of public institutions with the environment is based on the involvement of citizens, ensures transparency and equal treatment, enabling ethical social dialogue (Izdebski, 2007, pp. 14-18). Thanks to civic participation in the decision-making process, the distance between society and public organization is reduced, there is an increase in partner relations at the level of public organizations - citizens - enterprises, and there is greater acceptance of the changes introduced by recipients (Lenart, 2015, p. 312). However, for the management of the network of connections to be skilful and bring tangible benefits to all interested parties, it is necessary to use appropriate tools for this purpose.

\section{Characteristics of public governance tools}

The presented concept of public governance is based in Poland on such instruments as (Kołodziej-Hajdo, 2017, p. 162):

- public consultation,

- regulatory impact assessment,

- public-private partnership,

- participatory budget.

Social consultations are an element of participatory democracy when a joint discussion takes place in the process of law-making, resulting in specific agreements (Długosz \& Wygnański, 2005, p. 21). These consultations take into account the participation of social partners, who represent a broad spectrum of society, in public decision-making. In this process, representatives of public authorities together with the above-mentioned partners resolve important general issues (Krajewska, 2007, p. 127). In practice, public consultations may take place within the framework of, inter 
alia, consultations addressed to the local community or the whole society in order to find out the position on a given topic; public hearing; consultations with residents of local government units, based on the acts on municipal, poviat and voivodeship self-government; consulting projects in the legislative process by the Council of Ministers (Kulesza \& Sześciło, 2013, p. 120).

Another instrument of the public governance concept is the regulatory impact assessment system. It can be treated as a certain tool allowing for the most precise determination of all effects (benefits and costs) of the state intervention under consideration. A properly conducted regulatory impact assessment should carry a range of information that will contribute to the development of the most favorable decision conditions from the perspective of stakeholders and decision makers (Sakowicz, 2014 , p. 59). The regulatory impact assessment system is, therefore, a component of an extensive decision-making process, within which decisions are adopted as an effect (Knosala, 2011, p. 97):

- the process of collecting information,

- establishing the relationship between ends and means,

- analysis of the consequences of the legal act being constructed.

The purpose of applying the regulatory impact assessment system is to explain the role of submitted regulatory projects, the resulting hypothetical risks and possible options for achieving the formulated goals (Better Regulation ..., 2002, p. 51).

Public-private partnership also fits into the concept of public governance. Pursuant to the Act of December 19, 2008 on public-private partnership, it consists in “(...) joint implementation of a project based on the division of tasks and risks between the public entity and the private partner" (Art. 1 ust. 2 ustawy z dnia 19 grudnia $2008 \mathrm{r}$. o partnerstwie...). The private partner is obliged to carry out the project for the agreed remuneration and incur (in whole or in part) the expenses for its implementation. On the other hand, the public entity undertakes to cooperate in achieving the set goal, in a particular way by making its own contribution. At the same time, each party to the contract bears a specific risk of failure of the implemented project (Poniatowicz, 2011, p. 35).

Based on Art. 2 point 4 of the aforementioned Act, a project implemented under public-private partnership means (Art. 2 pkt. 4 ustawy z dnia 19 grudnia 2008 r. o partnerstwie...):

- construction or renovation of a building object,

- providing services,

- performance of a work, in particular equipping an asset with devices increasing its value or usefulness, or

- other benefit - connected with the maintenance or management of an asset that is used for the implementation of a public-private project or is related to it.

Public-private partnership is based on long-term cooperation, which covers a period of up to several dozen years. Making a decision to use this form of public 
task implementation requires looking beyond the time horizon of the term of office of persons performing managerial functions in a particular public entity (Kania, 2017, pp. 351-352). It should also be mentioned that there are different models of cooperation between the public entity and the private partner. They differ mainly in the scope of private engagement as well as in the amount of risk transferred to the private sector. ${ }^{1}$

Public governance instruments also include participatory budgeting. According to the definition formulated by one of the UN agencies, participatory budgeting is a mechanism by which the population decides or has a significant influence on the decisions made that relate to the method of allocating all or a specific part of the available public funds ( 72 Frequently..., 2004, p. 20). The essence of this budget is, therefore, based on the selection by the inhabitants - by voting - of tasks to be implemented in a particular financial year. The local initiative here comes down to the cooperation of the local government unit with the community in the course of the implementation of public tasks (Pabiś, 2017, p. 19). Thanks to the procedure of using the participatory budget, it is possible (Żabka \& Łapińska, 2014, p. 37):

- to identify the most important needs of specific groups of residents,

- to take initiatives to solve problems often unnoticed by local authorities,

- to exercise control over public expenditure to a certain extent,

- to stimulate civic activity.

It should also be noted that the participatory budget is not an independent financial plan that would be fully independent from the budget of a particular local government unit. In fact, it is a plan of allocating a specific amount from the budget of a local government unit, which the members of the local community can use to express their own position (Czarnecki, 2014, p. 131). The participatory budget most often includes such projects as the construction, extension or modernization of roads, water supply systems, sewage systems, buildings, as well as architectural objects owned by a particular local government unit (Pabiś, 2017, p. 20).

\section{The use of participatory budget as a public governance tool on the example of the city of Lublin}

The civic budget was first introduced in the Brazilian city of Porto Alegre in the 1980s. It was supposed to be a solution to the existing socio-economic problems of the city, including increasing poverty, increasing crime and social exclusion (Dias, 2014, p. 9). Participatory budgeting was extremely successful, which made it popular both in South America and elsewhere. Its dissemination was noticeable especially after the UN conference in Istanbul in 1996, when the Porto Alegre participatory budget was recognized as one of the 42 most effective solutions in the field of city

1 More on this: Poniatowicz (2011, pp. 40-41). 
management (Goldfrank, 2007, p. 93). The civic budget has also become the subject of numerous scientific studies. Patsias, Latendresse and Bherer focus on the effects of decentralization, and - more specifically - the form it took in the preparation of a participatory budget in Montreal (Patsias, Latendresse, \& Bherer, 2012), whereas Džzinić, Svidroňová and Markowska-Bzducha conducted a comparative analysis of the use and role of participatory budgets in Croatia, Poland and Slovakia and examined participatory budget models used in selected countries. In order to compare the case studies of municipalities in selected countries, a qualitative analysis was used and a classification of participatory budget models was applied (Džinić, Svidroňová, \& Markowska-Bzducha, 2016).

The participatory budget mechanism has been used in Poland since 2011. The first city in the country to implement the participatory budget was Sopot (Dworakowska, 2014, p. 63). However, among all provincial cities in Poland, such a solution was used for the first time in 2013 in Bydgoszcz, Gorzów Wielkopolski, Poznań, Wrocław and Zielona Góra (Kowalska-Chrzanowska, 2019, p. 62). In Lublin, the first edition of the participatory budget took place in 2015 (www5).

Table 1 presents general information on participatory budgets implemented in provincial cities in 2020 . When analyzing the data included in the list, it should be noted that the share of public funds allocated to the implementation of tasks under the participatory budget fluctuates from 0.30 to $0.96 \%$ of the total expenditure of the budget (in Lublin, this share is one of the highest among all provincial cities and amounts to $0.75 \%$ of total expenses). The highest share was recorded in Łódź, and the lowest - in Szczecin. In nominal terms, the highest amount allocated to the implementation of tasks under the participatory budget in 2020 was in Warsaw (over PLN 83 million), while the lowest - in Opole (PLN 5.2 million).

Table 1. General information on participatory budgets of voivodeship cities in Poland in 2020

\begin{tabular}{|l|r|c|c|c|}
\hline Provincial city & Population & $\begin{array}{c}\text { Total budget } \\
\text { expenses (PLN) }\end{array}$ & $\begin{array}{c}\text { Participatory budget } \\
\text { funds (PLN) }\end{array}$ & $\begin{array}{c}\text { Share of participatory budget } \\
\text { resources in total budget expenditure }\end{array}$ \\
\hline Warszawa & $1,790,658$ & $21,383,442,807$ & $83,026,847$ & $0.39 \%$ \\
\hline Białystok & 297,585 & $2,364,476,053$ & $11,987,318$ & $0.51 \%$ \\
\hline Bydgoszcz & 346,739 & $2,662,178,060$ & $17,912,839$ & $0.67 \%$ \\
\hline Gdańsk & 471,525 & $4,307,032,525$ & $18,115,608$ & $0.42 \%$ \\
\hline Gorzów Wlkp. & 123,341 & $1,109,193,692$ & $5,478,457$ & $0.49 \%$ \\
\hline Katowice & 291,774 & $2,600,182,409$ & $17,615,983$ & $0.68 \%$ \\
\hline Kielce & 197,218 & $1,543,394,413$ & $7,000,298$ & $0.45 \%$ \\
\hline Kraków & 780,981 & $6,734,688,690$ & $25,961,019$ & $0.39 \%$ \\
\hline Lublin & 339,547 & $2,542,235,303$ & $19,070,891$ & $0.75 \%$ \\
\hline Lódź & 677,286 & $5,207,793,066$ & $50,000,000$ & $0.96 \%$ \\
\hline Olsztyn & 171,853 & $1,439,055,818$ & $6,400,000$ & $0.44 \%$ \\
\hline Opole & 128,012 & $1,526,927,769$ & $5,200,000$ & $0.34 \%$ \\
\hline Poznań & 533,830 & $5,154,251,956$ & $21,000,000$ & $0.41 \%$ \\
\hline
\end{tabular}


Pobrane z czasopisma Annales H - Oeconomia http://oeconomia.annales.umcs.pl

Data: 26/04/2023 05:44:34

JAN BRAUN, PATRYCJA MARZEC-BRAUN

\begin{tabular}{|l|c|c|c|c|}
\hline Provincial city & Population & $\begin{array}{c}\text { Total budget } \\
\text { expenses (PLN) }\end{array}$ & $\begin{array}{c}\text { Participatory budget } \\
\text { funds (PLN) }\end{array}$ & $\begin{array}{c}\text { Share of participatory budget } \\
\text { resources in total budget expenditure }\end{array}$ \\
\hline Rzeszów & 196,821 & $1,692,831,242$ & $9,627,467$ & $0.57 \%$ \\
\hline Szczecin & 400,990 & $3,643,265,763$ & $10,797,525$ & $0.30 \%$ \\
\hline Toruń & 201,106 & $1,505,600,000$ & $7,410,000$ & $0.49 \%$ \\
\hline Wrocław & 643,782 & $5,652,356,730$ & $33,377,947$ & $0.59 \%$ \\
\hline Zielona Góra & 141,280 & $1,036,506,272$ & $6,958,651$ & $0.67 \%$ \\
\hline
\end{tabular}

Source: Authors' own study based on (www1; Uchwały budżetowe poszczególnych..., 2020).

At this point, a detailed analysis of data on Lublin's participatory budget will take place. It should be noted that Table 2 only covers the period up to 2019. This is due to the introduction of new rules that have been in force in the participatory budget of this city from the sixth edition (2020). The existing projects - small and large - have been replaced by projects (www6):

- district - with a value not exceeding PLN 300,000 which are to serve the residents of a particular district in a special way,

- city-wide - meeting at least one of the following conditions:

- concern at least two districts,

- exceed the amount of PLN 300,000 in value,

- are not of an investment nature.

Table 2. Basic data on the participatory budget of the city of Lublin (according to budget resolutions) in 2015-2019

\begin{tabular}{|l|l|c|c|c|c|c|}
\hline No. & \multicolumn{1}{|c|}{ Specification } & 2015 & 2016 & 2017 & 2018 & 2019 \\
\hline 1 & Participatory budget funds (PLN) & $10,212,382$ & $15,000,000$ & $20,879,299$ & $22,413,269$ & $25,735,721$ \\
\hline 2 & $\%$ of total city budget expenses & $0.57 \%$ & $0.88 \%$ & $0.99 \%$ & $0.96 \%$ & $1.11 \%$ \\
\hline 3 & $\begin{array}{l}\text { Funds allocated to small projects } \\
\text { (PLN) }\end{array}$ & $6,112,382$ & $8,000,000$ & $8,000,000$ & $8,978,542$ & $9,000,000$ \\
\hline 4 & $\begin{array}{l}\text { Funds allocated to large projects } \\
\text { (PLN) }\end{array}$ & $4,100,000$ & $7,000,000$ & $7,000,000$ & $4,800,000$ & $6,000,000$ \\
\hline \multirow{2}{*}{5} & $\begin{array}{l}\text { Number of projects approved for } \\
\text { implementation }\end{array}$ & 30 & 25 & 23 & 43 & 44 \\
\cline { 2 - 7 } & - small & 27 & 19 & 17 & 39 & 39 \\
\cline { 2 - 7 } & - large & 0 & $\mathrm{n} / \mathrm{a}$ & $5,879,299$ & $7,413,269$ & $10,735,721$ \\
\hline \multirow{2}{*}{6} & $\begin{array}{l}\text { Amount for tasks that have not } \\
\text { been completed in previous } \\
\text { editions (PLN) }\end{array}$ & & 6 & 4 & 5 \\
\hline
\end{tabular}

$\mathrm{n} / \mathrm{a}$ - no data available

Source: Authors' own study based on (Uchwały budżetowe miasta...).

The above data shows that the share of the participatory budget amount in the total budget expenditure in the analyzed period fluctuates from 0.57 to $1.11 \%$. Taking into account the last 2 years, this share was, respectively: $0.75 \%$ in 2020 and $0.46 \%$ 
in $2021 .^{2}$ There is also an upward trend in the amount allocated to the implementation of tasks under the participatory budget: from over PLN 10 million in the first edition to nearly PLN 26 million in the fifth edition. This tendency has not been maintained for the last 2 years - the amount of funds from the participatory budget in 2021 is slightly more than PLN 13 million (Uchwały budżetowe miasta...). When referring to the number of projects approved for implementation, it should be noted that small projects (in the last two years - district projects) dominate, which is reflected in a larger pool of funds allocated for their implementation.

In 2021, 40 draft citizens' budgets in Lublin were voted on. The projects are of a district and city-wide character. Table 3 provides a brief description of some of the winning projects from 2021.

Table 3. Selected winning projects of the seventh edition of Lublin's participatory budget

\begin{tabular}{|l|c|c|l|}
\hline \multicolumn{1}{|c|}{ Project name } & $\begin{array}{c}\text { Project } \\
\text { type }\end{array}$ & $\begin{array}{c}\text { Investment } \\
\text { value (PLN) }\end{array}$ & \multicolumn{1}{|c|}{ Description } \\
\hline $\begin{array}{l}\text { D-11 Zielone Śród- } \\
\text { mieście }\end{array}$ & district & 10,000 & $\begin{array}{l}\text { The project includes planting trees in Śródmieście at Ewan- } \\
\text { gelicka and Zesłańców Sybiru streets }\end{array}$ \\
\hline D-38 Jasne Szerokie & district & 272,000 & $\begin{array}{l}\text { The project involves the construction of lighting for three } \\
\text { pedestrian routes in the Szerokie district. }\end{array}$ \\
\hline $\begin{array}{l}\text { D-103 Bądźmy dumni } \\
\text { ze Starego Miasta } \\
\text { w Lublinie }\end{array}$ & district & 300,000 & $\begin{array}{l}\text { The project includes the renovation and illumination of the } \\
\text { only surviving Semicircular Tower which was part of the } \\
\text { defense system of the Old Town. This will improve the image } \\
\text { and aesthetics of Lublin's Old Town. }\end{array}$ \\
\hline $\begin{array}{l}\text { O-1 Aktywny Lublin } \\
\text { wide }\end{array}$ & $\begin{array}{l}\text { city- } \\
\text { city- } \\
\text { wide }\end{array}$ & $1,500,000$ & $\begin{array}{l}\text { The project is a continuation of last year's task and consists } \\
\text { in organizing sports activities for willing residents of Lublin. }\end{array}$ \\
\hline $\begin{array}{l}\text { O-3 Zalew Zemborzy- } \\
\text { cki miejscem wy- } \\
\text { poczynku wszystkich } \\
\text { lublinian }\end{array}$ & $\begin{array}{l}\text { The project includes, among others, renovation of approx. } \\
\text { River. }\end{array}$ \\
\hline $\begin{array}{l}\text { O-16 Lublin przeciw } \\
\text { zanieczyszczeniu } \\
\text { powietrza - drzewa dla } \\
\text { każdej dzielnicy }\end{array}$ & $\begin{array}{l}\text { city- } \\
\text { wide }\end{array}$ & $1,014,000$ & $\begin{array}{l}\text { The project includes the purchase and planting trees in the bicycle route along the Bystrzyca } \\
\text { districts of Lublin. }\end{array}$ \\
\hline
\end{tabular}

Source: Authors' own study based on (www7).

The next two tables (4 and 5) provide detailed information on all editions of Lublin's participatory budget. The largest number of projects was submitted under the first edition in 2015. In the following years, the number of submitted proposals gradually decreased, with the exception of the fifth edition in 2019, when an increase in the number of projects was recorded compared to the previous year. The percentage of projects that meet all formal requirements, and hence are eligible for voting, usually fluctuates between 70 and $87 \%$ of all submitted projects (the exception is

2 Authors' own calculations based on the data available in the budget resolutions of the city of Lublin for 2020 and 2021. 
the last edition, in which $58 \%$ of submitted projects were allowed to vote). About 40 projects were accepted for implementation in the last four editions.

It should be expected that the greater the number of projects allowed to be voted under the participatory budget, the greater the turnout can be expected in a particular edition. However, after analyzing the data on the number of projects and the data showing the number of voters, it should be stated that in the case of Lublin's participatory budget, such a relationship does not occur. The highest turnout was recorded in 2017, while the largest number of projects admitted to voting occurred in the first edition in 2015. Persons participating in voting on projects have the opportunity to vote both in paper and online form. Since the fourth edition, people voting via the Internet have definitely dominated (the percentage of voting in this mode among the total number of voters is constantly over $90 \%$ ). There should also be a downward trend in the number of people voting from 2018.

Table 4. Summary of data from individual editions of the participatory budget regarding the number of projects

\begin{tabular}{|l|c|c|c|}
\hline $\begin{array}{c}\text { Edition of a participatory } \\
\text { budget }\end{array}$ & $\begin{array}{c}\text { Number of submitted } \\
\text { projects }\end{array}$ & $\begin{array}{c}\text { Number of projects } \\
\text { allowed to vote (\% of } \\
\text { projects submitted) }\end{array}$ & $\begin{array}{c}\text { Number of projects } \\
\text { approved for } \\
\text { implementation }\end{array}$ \\
\hline $1^{\text {st }}$ edition 2015 & 333 & $233(70 \%)$ & 29 \\
\hline $2^{\text {nd }}$ edition 2016 & 210 & $155(74 \%)$ & 25 \\
\hline $3^{\text {rd }}$ edition 2017 & 171 & $149(87 \%)$ & 23 \\
\hline $4^{\text {th }}$ edition 2018 & 157 & $118(75 \%)$ & 43 \\
\hline $5^{\text {th }}$ edition 2019 & 223 & $165(74 \%)$ & 44 \\
\hline $6^{\text {th }}$ edition 2020 & 201 & $142(71 \%)$ & 40 \\
\hline $7^{\text {th }}$ edition 2021 & 156 & $91(58 \%)$ & 40 \\
\hline
\end{tabular}

Source: Authors' own study based on (Lubelska...; www3; www4).

Table 5. Summary of data from individual editions of the participatory budget regarding the number of votes

\begin{tabular}{|l|c|c|c|}
\hline $\begin{array}{c}\text { Edition of a participatory } \\
\text { budget }\end{array}$ & $\begin{array}{c}\text { Number of paper voters } \\
\text { (percentage of total } \\
\text { voters) }\end{array}$ & $\begin{array}{c}\text { Number of online voters } \\
\text { (percentage of total } \\
\text { voters) }\end{array}$ & $\begin{array}{c}\text { The sum of paper and } \\
\text { electronic voters in } \\
\text { a participatory budget }\end{array}$ \\
\hline $1^{\text {st }}$ edition 2015 & $19,843(42 \%)$ & $27,272(58 \%)$ & 47,115 \\
\hline $2^{\text {nd }}$ edition 2016 & $43,621(64 \%)$ & $24,405(36 \%)$ & 68,026 \\
\hline $3^{\text {rd }}$ edition 2017 & $55,721(76 \%)$ & $17,748(24 \%)$ & 73,469 \\
\hline $4^{\text {th }}$ edition 2018 & $1,286(3 \%)$ & $37,386(97 \%)$ & 38,672 \\
\hline $5^{\text {th }}$ edition 2019 & $2,596(10 \%)$ & $22,722(90 \%)$ & 25,318 \\
\hline $6^{\text {th }}$ edition 2020 & $2,180(8 \%)$ & $23,635(92 \%)$ & 25,815 \\
\hline $7^{\text {th }}$ edition 2021 & $1,112(6 \%)$ & $17,121(94 \%)$ & 18,233 \\
\hline
\end{tabular}

Source: Authors' own study based on (Lubelska...; Raport...; www3; www2).

To conclude the analyzes carried out in this part of the study, it should be stated that the participatory budget of the city of Lublin experiences a significant decline 
in interest. Referring to the report Budżet obywatelski w polskich miastach (Miasto 2077, 2019, p. 2), it should be noted that similar trends are also noticeable in other provincial cities in the country. However, despite the declining attendance, this does not translate proportionally to the number of projects both submitted and approved for implementation. On the other hand, the scale and number of winning projects do not affect the degree of interest in a participatory budget. Moreover, in recent years, a significant increase in the share of people voting online has been noticeable.

\section{Conclusions}

The participatory budget, as one of the public governance tools, is the basis for the cooperation of residents with local authorities through the active involvement of the local community in deciding on the allocation of public funds. The aforementioned cooperation is reflected both in the possibility of submitting project proposals to the participatory budget of a given edition, as well as in the subsequent voting for projects that meet all formal requirements.

The conclusions and recommendations resulting from the conducted analyzes are as follows:

1. The application of the participatory budget increases the transparency of spending a certain pool of public funds, allocating strictly defined amounts to selected projects.

2. Lublin's participatory budget is characterized by a relatively high share of funds allocated for the implementation of tasks in total budget expenditure compared to other voivodeship capital cities in Poland.

3. There is a downward trend in terms of the number of projects submitted to the participatory budget of Lublin.

4. For several years, a decline in the turnout of people voting for projects under the participatory budget has been visible.

5. A recommendation for local authorities is to intensify activities aimed at popularizing the participatory budget as a public governance tool among the local community.

6. Promoting the idea of civic budget on a large scale will increase the awareness and activity of members of the local community in the field of co-decision in the area of implemented projects.

This study is a prelude to further detailed research on the distribution of public funds with the use of participatory budgeting. The above analyzes are still up-todate and interesting both from the perspective of local government authorities and the local community. 


\section{References}

72 Frequently Asked Questions about Participatory Budgeting. (2004). Global Campaign on Urban Governance. UN-HABITAT, Quito.

Art. 1 ust. 2 ustawy z dnia 19 grudnia 2008 r. o partnerstwie publiczno-prywatnym (Dz.U. $2009 \mathrm{Nr} 19$ poz. 100 z późn. zm.).

Art. 2 pkt. 4 ustawy z dnia 19 grudnia 2008 r. o partnerstwie publiczno-prywatnym (Dz.U. $2009 \mathrm{Nr} 19$ poz. 100 z późn. zm.).

Better Regulation: Making Good Use of Regulatory Impact Assessments. (2002). National Audit Office. Report of the Controller and Auditor General HC 329 Session 2001-2002, London.

Czarnecki, K. (2014). Udział mieszkańców w ustalaniu wydatków budżetu gminy w ramach tzw. budżetu partycypacyjnego (na przykładzie Torunia w latach 2013-2014). Prawo Budżetowe Państwa i Samorzadu, 1(2), 125-145. https://doi.org/10.12775/PBPS.2014.008

Dias, N. (2014). Hope for Democracy. 25 Years of Participatory Budgeting Worldwide. São Brás de Alportel: In Loco Association.

Długosz, D., \& Wygnański, J.J. (2005). Obywatele współdecydują. Przewodnik po partycypacji społecznej. Warszawa: Stowarzyszenie na Rzecz Forum Inicjatyw Pozarządowych.

Dworakowska, M. (2014). Rola i znaczenie budżetu partycypacyjnego w rozwoju społeczeństwa obywatelskiego. In J. Osiński \& J.Z. Popławska (red.), Oblicza społeczeństwa obywatelskiego. Państwo. Gospodarka. Świat (pp. 30-40). Warszawa: SGH.

Džinić, J., Svidroňová, M.M., \& Markowska-Bzducha, E. (2016). Participatory Budgeting: A Comparative Study of Croatia, Poland and Slovakia. NISPAcee Journal of Public Administration and Policy, 9(1), 31-56. https://doi.org/10.1515/nispa-2016-0002

Goldfrank, B. (2007). Lessons from Latin American Experience in Participatory Budgeting. In A. Shah (Ed.), Participatory Budgeting. Public Sector Governance and Accountability Series. Washington: World Bank.

Izdebski, H. (2007). Od administracji publicznej do public governance. Zarzadzanie Publiczne, 1(1), 7-20.

Jasińska, K. (2015). Wybrane obszary nowego zarządzania publicznego w sektorze samorządowym w Polsce. Zeszyty Naukowe Politechniki Częstochowskiej. Zarządzanie, 18, 69-81.

Jessop, B. (2007). Promowanie „dobrego rządzenia” i ukrywanie jego słabości: refleksja nad politycznymi paradygmatami i politycznymi narracjami w sferze rządzenia. Zarzadzanie Publiczne, 2(2), 5-25.

Kania, M. (2017). Partnerstwo publiczno-prywatne. In R. Blicharz (red.), Przedsiębiorca: zagadnienia wybrane (pp. 347-369). Katowice: UŚ.

Kargol-Wasiluk, A., \& Wojewódko, E. (2016). Budżet zadaniowy jako narzędzie poprawy jakości rządzenia (na przykładzie Podlaskiego Urzędu Wojewódzkiego). Optimum. Studia Ekonomiczne, 2(86), 155-177. https://doi.org/10.15290/ose.2017.02.86.11

Knosala, E. (2011). Zarys teorii decyzji w nauce administracji. Warszawa: Wolters Kluwer Polska.

Kołodziej-Hajdo, M. (2017). Budżet partycypacyjny jako instrument zarządzania publicznego w koncepcji „public governance” na przykładzie miasta Krakowa. Studia Ekonomiczne. Zeszyty Naukowe Uniwersytetu Ekonomicznego w Katowicach, 341, 159-170.

Kotowska, E. (2015). Implementacja metod i narzędzi zarządzania menedżerskiego w sektorze publicznym. In W. Harasim (red.), Zarządzanie wartościami niematerialnymi w erze gospodarki cyfrowej (pp. 31-47). Warszawa: Wyższa Szkoła Promocji, Mediów i Show Businessu.

Kowalska-Chrzanowska, M. (2019). Budżet obywatelski jako instrument partycypacji społecznej w obszarze kultury. Zarządzanie w Kulturze, 20(1), 57-77. https://doi.org/10.4467/20843976ZK.19.004.10337

Krajewska, A. (2007). Konsultacje społeczne w praktyce. Studium dwóch przypadków. In M. Rymsza (red.), Organizacje pozarzadowe. Dialog obywatelski. Polityka państwa (pp. 127-154). Warszawa: FISP.

Kulesza, M., \& Sześciło, D. (2013). Polityka administracyjna i zarządzanie publiczne. Warszawa: Wolters Kluwer Polska. 
Lenart, R. (2015). Współzarządzanie a rozwój organizacji publicznej. Marketing i Rynek, 9(CD), 309-319. Lubelska Grupa Badawcza. Ewaluacja Budżetu Obywatelskiego 2018.

Miasto 2077. (2019). Raport: Budzet Obywatelski w polskich miastach.

Myszak, J.M. (2012). Nowe zarządzanie publiczne (NPM) jako instrument zarządzania finansami publicznymi. Zeszyty Naukowe Uniwersytetu Szczecińskiego. Współczesne Problemy Ekonomiczne. Globalizacja. Liberalizacja. Etyka, 5, 109-120.

Pabiś, Ł. (2017). Zrównoważony rozwój w kontekście nowych koncepcji zarządzania publicznego: „New Public Management” i „Public Governance” (nowego zarządzania publicznego i zarządzania partycypacyjnego). Zeszyty Naukowe Politechniki Częstochowskiej: Zarządzanie, 25(2), 7-22. https://doi.org/10.17512/znpcz.2017.1.2.01

Patsias, C., Latendresse, A., \& Bherer, L. (2012). Participatory Democracy, Decentralization and Local Governance: The Montreal Participatory Budget in the Light of 'Empowered Participatory Governance'. International Journal of Urban and Regional Research, 37(6), 2214-2230. https://doi.org/10.1111/j.1468-2427.2012.01171.x

Poniatowicz, M. (2011). Partnerstwo publiczno-prywatne w sektorze samorządowym a problematyka lokalnego długu publicznego. Optimum. Studia Ekonomiczne, 3(51).

Raport dotyczacy Budzetu Obywatelskiego 2020. Lubelska Grupa Badawcza.

Rudolf, W. (2010). Koncepcja governance i jej zastosowanie-od instytucji międzynarodowych do niższych szczebli władzy. Acta Universitatis Lodziensis, Folia Oeconomica, 245, 73-82.

https://doi.org/11089/527

Rybczyńska, J.A. (2002). Partycypacja obywatelska na poziomie lokalnym w III Rzeczypospolitej Polskiej - próba oceny. In S. Michałowski (red.), Samorząd terytorialny III Rzeczypospolitej. Dziesięć lat doświadczeń (pp. 113-120). Lublin: Wydawnictwo UMCS. https://doi.org/10.6084/m9.figshare.94199

Sakowicz, M. (2014). Rola oceny skutków regulacji w dobie kryzysu ekonomicznego. Doświadczenia polskiej administracji. In W. Mikułowski \& A. Jezierska (red.), Administracja publiczna wobec wyzwań kryzysu ekonomicznego i jego konsekwencji społecznych (pp. 58-70). Warszawa: KSAP.

Sempiak, A. (2017). Nowe zarządzanie publiczne - kierunki zmian w funkcjonowaniu sektora publicznego. Samorzad terytorialny: organizacja, funkcjonowanie i kierunki rozwoju, 41(2), 143-155.

Stefańska, D., Bubel, D., \& Barcik, A. (2019). Zarządzanie kapitałem intelektualnym w perspektywie nowego zarządzania publicznego. Zeszyty Naukowe Politechniki Częstochowskiej. Zarzadzanie, 34, 135-144. https://doi.org/10.17512/znpcz.2019.2.12

Szumowski, W. (2014). Zarządzanie publiczne - próba systematyzacji koncepcji. Nauki o Zarządzaniu, $4(21), 86-98$.

Uchwały budżetowe miasta Lublin na lata 2015-2021.

Uchwały budżetowe poszczególnych miast na rok 2020.

Zalewski, A. (2006). Teoria i praktyka nowego zarządzania publicznego. In M. Ostaszewski \& M. Zaleska (red.), W stronę teorii i praktyki finansów (p. 74). Warszawa: SGH.

Ziębicki, B. (2014). Efektywność organizacyjna podmiotów sektora publicznego. Kraków: UE.

Żabka, A., \& Łapińska, H. (2014). Budżet partycypacyjny a rozwój lokalny. Zeszyty Naukowe Wyższej Szkoly Finansów i Prawa, 4, 36-63.

\section{Internet sources}

www1. Retrieved from https://demografia.stat.gov.pl/BazaDemografia/StartIntro.aspx www2. Retrieved from https://kurierlubelski.pl/budzet-obywatelski-2019-znamy-wyniki-najwiekszymwygranym-stadion-zuzlowy/ar/13613992

www3. Retrieved from https://lublin.budzet-obywatelski.eu/wyniki www4. Retrieved from https://lublin.eu/mieszkancy/partycypacja/budzet-obywatelski/aktualnosci/ 
Pobrane z czasopisma Annales H - Oeconomia http://oeconomia.annales.umcs.pl Data: 26/04/2023 05:44:34

JAN BRAUN, PATRYCJA MARZEC-BRAUN

www5. Retrieved from https://lublin.eu/mieszkancy/partycypacja/budzet-obywatelski/budzet-obywatelski-2015/10-mln-zl-na-budzet-obywatelski-w-lublinie,14,676,1.html

www6. Retrieved from https://www.lublin.eu/mieszkancy/partycypacja/budzet-obywatelski/budzet-obywatelski-vi-edycja/nowe-zasady/

www7. Retrieved from https://lublin.eu/mieszkancy/partycypacja/budzet-obywatelski/budzet-obywatelski-vii/zwycieskie-projekty/ 